\title{
obituary
}

\section{Michael Abercrombie}

Mr Michael Abercrombie FRS, Director of the Strangeways Research Laboratory, Cambridge, who was distinguished for his contributions to the study of cell locomotory behaviour and malignant invasion in tissue culture, died of cancer on 28 May 1979 after a protracted illness. The importance of his scientific achievement lies as much in his almost single-handed establishment of new general aproaches to the problems of development and malignancy as in the details of his own work. His goodhumoured courtesy, fairness and deep humanity captured the devotion of all he met throughout the world.

Michael Abercrombie was born on 14 August 1912, at Rhyton Dymock, Gloucestershire. His father, Lascelles Abercrombie, was a distinguished poet and literary critic who later became the Goldsmith Reader at Oxford. In 1931 Michael Abercrombie obtained a Hastings scholarship to read zoology at Queen's College, Oxford. One of his tutors there was Gavin de Beer, an immensely erudite descriptive embryologist, who stimulated his interest in experimental embryology. He left Oxford in 1934 with a 1st in zoology and moved to the Strangeways Laboratory in Cambridge to work with C.H. Waddington who had a dazzling and fascinating influence on him. Here he experimented on the primitive streak in early blastoderms and, for this work, he obtained an Oxford BSc which was then a research degree.

Shortly before the war, he met M.L. Johnson (Jane) at Birmingham University and they were soon married. They spent the war years working together on the degeneration and regeneration of peripheral nerve, a programme of work supervised by J.Z. Young and chosen because of its possible usefulness to wartime surgery. This work was largely carried out in the Anatomy Department at Birmingham but the laboratory was not equipped and Michael had to surrender his superannuation in order to raise money for apparatus. I believe that at the same time he sold his wife's car; her sacrifice surpasses that of Faraday's wife whose linen gown was shredded into strips in order to insulate a coil!

After the war, he took up a lectureship in the Anatomy Department at University College London where J.Z. Young held the chair and here he became reader in charge of the Sub-department of Embryology and eventually, in 1959, a second chair was created for him within the department. Under his leadership, the subdepartment soon became a major centre for embryology in Britain and out of it came the Journal of Embryology and Experimental Morphology. In 1962 he became Jodrell Professor of Zoology at University College and, in 1970, he succeeded Honor Fell as Director of the Strangeways Laboratory from which he was to retire in the autumn of 1979.

Michael Abercrombie was a founder member of the London Embryologists' Club which first met in November 1947 and which later became the British Society for Development Biology. He was also elected a Fellow of the Institut International d'Embryologie in 1956, a Fellow of the Royal Society in 1958 and was awarded an honorary doctorate by the University of Uppsala in Sweden in 1977.

The main theme of Abercrombie's research was a study of how signals which control locomotory behaviour are communicated between cells. He early noticed that the Schwann cells associated with regenerating peripheral nerve stumps in culture cease to move once the stumps have met and he soon performed the classic experiment of using time lapse cinematography to observe the behaviour of locomoting fibroblasts in a culture consisting of two confronted explants of chick heart tissue. In 1950 he was joined in this work by Joan Heaysman and they started the publication of their results in 1953.

These papers were of enormous importance to biology. They released a powerful new technique - the careful quantitative analysis of cell behaviour and simultaneously revealed what has since proved to be probably the most important of the behavioural reactions, contact inhibition of locomotion. With Jack Ambrose, Abercrombie made a cytological study of contact inhibition in both normal and malignant cells and the resulting paper became the ninth most highly quoted in cancer in the period 1960-1975. It initiated an interest in the relation of the cell surface to malignancy which swept the cancer research world.

Until his retirement, he continued to work on models of malignant invasion in culture with Joan Heaysman and Pat Stephenson but, in the mid sixties, the emphasis of his research changed to the machinery of cell locomotion and Sue Pegrum, an electron microscopist, joined the group at University College. Later, when I moved with him to the Strangeways Laboratory, this subject became the main interest of our small research group. Among the topics more peripheral to the central theme, he continued his early primitive streak experiments with Ruth Bellairs, worked on liver regeneration with R.D. Harkness and investigated collagen formation during wound healing with D.W. James.

Michael Abercrombie's scientific ability was impressive. His command of techniques and comprehensive knowledge of the literature were matched only by his imaginative insight, his dogged pursuit of a problem and his high standard of objective evidence. His reluctance to speculate or to place too simple an interpretation on his results often made his papers hard going for the reader and sometimes led to the oversimplification or outright misrepresentation of his work by others.

In scientific discussion, as always, he was just and courteous. He spoke little (in his own opinion he was almost neurotically shy) and preferred to listen, but what he did say was very carefully thought out and well worth close study. He was extraordinarily knowledgeable not only within science (he read a minimum of 50 papers in preparation for each lecture to his students) but also in music, painting, literature and politics, rivalling, although he would never have agreed, the breadth of learning which he so admired in his friends Lancelot Hogben, J.B.S. Haldane and Gavin de Beer. Nevertheless, he remained totally modest and unassuming, never averse to humble tasks, even after attaining international distinction. He was patiently tolerant of shortcomings in others and was acutely sympathetic towards oppressed or unfortunate people, spending much of his time unobtrusively helping them.

These, then, were the qualities which have endeared Michael Abercrombie to so many. Perhaps his most extraordinary achievement is that, without exception, all who knew him well had a profound respect and fond regard for him. He overcame the hardships and endured the irony of his final illness with typical stoicism and good humour.

Graham A. Dunn

\section{Julia Bell}

Julia Bell, FRCP died on 26 April 1979, shortly after her 100th birthday. She was one of the pioneers of human genetics and worked at University College London throughout her life.

Like many human geneticists she came into the subject from mathematics, which she had studied at Girton, and she worked as Karl Pearson's statistical assistant from 